\title{
EDNRA wt Allele
}

National Cancer Institute

\section{Source}

National Cancer Institute. EDNRA wt Allele. NCI Thesaurus. Code C71439.

Human EDNRA wild-type allele is located in the vicinity of $4 q 31.23$ and is approximately $64 \mathrm{~kb}$ in length. This allele, which encodes endothelin-1 receptor protein, is involved in the initiation of endothelin-1 protein-dependent signal transduction. 